УДК 616.379-008.64 + 577.128

https://doi.org/10.17816/MAJ19237-42

\title{
THE SPECIFIC ACTIVITY OF PROTEINS INVOLVED IN IRON METABOLISM DEPENDS ON COMPENSATION OF TYPE 2 DIABETES MELLITUS
}

\author{
I.V. Voynova1, V.A. Kostevich1', A.Yu. Elizarova1, M.N. Karpenko1, A. V. Sokolov'1,2 \\ ${ }^{1}$ Institute of Experimental Medicine, Saint Petersburg, Russia; \\ ${ }^{2}$ Saint Petersburg State University, Saint Petersburg, Russia
}

For citation: Voynova IV, Kostevich VA, Elizarova AYu, et al. The specific activity of proteins involved in iron metabolism depends on compensation of type 2 diabetes mellitus. Medical Academic Journal. 2019;19(2):37-42. https://doi.org/10.17816/MAJ19237-42

Received: April 10, 2019

Revised: May 24, 2019

Accepted: May 30, 2019

Objective. We aimed to analyze the alterations of activity of iron metabolism members i.e. ceruloplasmin (Cp) and transferrin (Tf), in relation to the percentage of glycated hemoglobin. The latter is one of biochemical criteria of chronic hyperglycemia compensation in case of type 2 diabetes mellitus.

Materials and methods. Concentration and activity of $\mathrm{Cp}$ and $\mathrm{Tf}$, concentration of iron, copper and lipoprotein cholesterol were measured by biochemical methods in blood serum samples obtained from healthy donors and patients with type 2 diabetes mellitus divided in three groups according to glycated hemoglobin level.

Results. The significant decrease in serum copper, ferroxidase activity of $\mathrm{Cp}$ and iron-binding capacity of $\mathrm{Tf}$, as well as an increase of $\mathrm{Tf}$ concentration, in groups with compensated and uncompensated type 2 diabetes mellitus was found.

Conclusion. Our data demonstrate a statistical link between the degree of type 2 diabetes mellitus compensation and alteration of iron metabolism members' activity. Thus, an increase of hyperglycemia is associated with a decrease of both $\mathrm{Cp}$ ferroxidase activity and the degree of $\mathrm{Tf}$ saturation with iron. These alterations may explain the efficiency of treatment with iron chelators of such type 2 diabetes mellitus complications as trophic ulcers. The said disease condition is directly connected with the changes in iron efflux.

Keywords: diabetes mellitus; glycated hemoglobin; transferrin; ceruloplasmin; iron; copper; ferroxidase activity; lipoproteins.

\section{ЗАВИСИМОСТЬ УАЕАЬНОЙ АКТИВНОСТИ УЧАСТНИКОВ ОБМЕНА ЖЕАЕЗА ОТ СТЕПЕНИ КОМПЕНСАЦИИ САХАРНОГО АИАБЕТА 2-ГО ТИПА}

\author{
И.В. Войнова', В.А. Костевич1, А.Ю. Елизарова', М.Н. Карпенко ${ }^{1}$, А.В. Соколов ${ }^{1,2}$ \\ ${ }^{1}$ ФГБНУ «Институт экспериментальной медицины», Санкт-Петербург; \\ 2 ФГБОУ ВПО «Санкт-Петербургский государственный университет», Санкт-Петербург
}

Для цитирования: Войнова И.В., Костевич В.А., Елизарова А.Ю., и др. Зависимость удельной активности участников обмена железа от степени компенсации сахарного диабета 2-го типа // Медицинский академический журнал. - 2019. - Т. 19. - № 2. - С. 37-42. https://doi.org/10.17816/MAJ19237-42

Поступила: 10.04.2019 Одобрена: 24.05.2019

Принята: 30.05 .2019

Цель исследования - проанализировать изменения активности участников обмена железа, церулоплазмина и трансферрина у пациентов с сахарным диабетом 2-го типа в зависимости от процентного содержания гликированного гемоглобина, который является биохимическим критерием степени компенсации хронической гипергликемии.

Mатериаль и методы. С помощью биохимических методов измерены концентрация и активность церулоплазмина и трансферрина, концентрация железа, меди, холестерина липопротеинов в сыворотке крови, полученной от здоровых доноров и пациентов с сахарным диабетом 2-го типа, объединенных в три группы в зависимости от процентного содержания гликированного гемоглобина.

Результаты. Обнаружены достоверное снижение концентрации меди, ферроксидазной активности церулоплазмина и способности трансферрина насыщаться железом, а также увеличение концентрации трансферрина при компенсированном и некомпенсированном сахарном диабете 2-го типа.

Заключение. Установлена статистическая связь степени компенсации сахарного диабета 2-го типа с активностью участников обмена железа. Так, по мере усиления гипергликемии снижается как активность церу-

List of abbreviations

$\mathrm{Cp}-$ ceruloplasmin, HbAlc - glycated hemoglobin, HDL - high-density lipoproteins, LDL - low-density lipoproteins, T2D - type 2 diabetes mellitus, $\mathrm{Tf}-$ transferrin, TIBC - total iron-binding capacity (of blood serum). 
лоплазмина, так и насыщение трансферрина ионами железа. Выявленные изменения объясняют причину эффективности лечения хелаторами железа таких осложнений сахарного диабета 2-го типа, как трофические язвы, которые связаны с изменением оттока железа.

Ключевые слова: сахарный диабет; гликированный гемоглобин; трансферрин; церулоплазмин; железо; медь; ферроксидазная активность; липопротеины.

\section{Introduction}

Type 2 diabetes mellitus (T2D) is associated with iron metabolism disorders, including those of hereditary etiology [1]. Indeed, T2D is found in about $80 \%$ of cases of hereditary hemochromatosis, which is associated with mutations in genes controlling iron metabolism: HFE (hemochromatosis protein), HAMP (hepcidin), TFR2 (transferrin receptor), SLC4OA1 (ferroportin), and HFE2 (hemojuvelin) [1]. $\mathrm{Cp}$ is the major ferroxidase in blood plasma [2]. Aceruloplasminemia being the result of a mutation in ceruloplasmin $(C p)$ gene is also associated with T2D. Recently double knockout of $\mathrm{Cp}$ and its homologue hephaestin $(\mathrm{Hp})$ genes was demonstrated to cause T2D symptoms in mice [3].

Chronic hyperglycemia in T2D is connected with non-enzymatic biopolymers modification by glucose, as well as by products of glucose oxidation: glyoxal, methylglyoxal etc. The percentage of glycated hemoglobin (HbAlc) is the widely accepted biochemical criterion of chronic hyperglycemia and its compensation. HbAlc level between $5.7 \%$ and $6.4 \%$ marks prediabetes or hyperglycemia compensated by therapy, while in case of uncompensated T2D HbAlc level exceeds 6.5\%. Continuously high level of glucose leads an increase of HbAlc percentage due to relatively low rate of red blood cells renewal (half-life period is about 60-90 days). However, other proteins, e.g. human serum albumin, are also targeted by nonenzymatic glycation [4]. Diminution of Cp activities due to aggregation, losing of copper ions and therefore the decreasing ferroxidase activity after in vitro modification by methylglyoxal or aminoacetone has been shown. The latter metabolites' levels are elevated in blood plasma in T2D patients $[5,6]$. The level of the so-called non-ceruloplasmin copper is increased in blood serum of T2D patients [7]. Although $\mathrm{Cp}$ does not form a stable complex with transferrin (Tf) [8], its physiological function is acceleration of loading into $\mathrm{Tf}$ of ferric ions produced during $\mathrm{Cp}$-catalyzed ferroxidase reaction [9]. Recently the glycation sites in both $\mathrm{Cp}$ and $\mathrm{Tf}$ were identified in T2D patients $[10,11]$. However, no significant correlations between HbAlc and serum iron, as well as between HbAlc and TIBC were found in T2D [12]. Taking into account that alteration of $\mathrm{Cp}$ ferroxidase activity in case of hereditary pathology of copper metabolism is usually compensated by low-density lipo- protein (LDL)-associated ferroxidase activity [13], the study of the link between T2D and cholesterol level can also be informative.

This study aims at analyzing the alteration of activity of the proteins of iron-metabolism proteins, e.g. $\mathrm{Cp}$ and $\mathrm{Tf}$. In parallel the lipoproteins and cholesterol, iron and copper levels were assayed in blood serum from healthy donors and T2D patients divided in three groups according to HbAlc level.

\section{Materials and methods}

This study included samples from 364 donors divided in three groups: Group $1-110$ donors without T2D (HbAlc $<5.8 \%)$; Group $2-$ 195 patients with compensated stage of T2D $(5.9 \%<\mathrm{HbA} 1 \mathrm{c}<6.9 \%)$; Group $3-59$ patients with uncompensated T2D (HbAlc $>6.9 \%)$. Acute phase of inflammation characterized by elevated level of C-reactive protein $(>10 \mathrm{mg} / \mathrm{L})$ was an exclusion criterion. Local institutional ethics committee approved the study (No. 2/19, 25.03.2019) and all participating subjects gave written informed consent to be included in the study for blood sampling. Blood serum samples were the courtesy of biochemical laboratories of Saint Petersburg State Clinical and Diagnostic Center No. 1.

Percentage of HbAlc was determined by the certified method [14] based on fast liquid chromatographic separation of hemoglobin obtained from red blood cells lysate using D-10 chromatograph and the reagent kit from Bio-Rad Laboratories (USA).

Concentrations of $\mathrm{Cp}$ and $\mathrm{Tf}$ in blood serum were determined with radial immunodiffusion according to Mancini [15]. Highly purified Cp and Tf were used to obtain monovalent rabbit antisera and to plot calibration curves reflecting the dependence of the area of immune precipitate on concentration of $\mathrm{Cp}$ or $\operatorname{Tf}[8,16,17]$.

Ferroxidase activity of $\mathrm{Cp}$ was determined with the help of automated method adapted for biochemical analyzer BS-200 (Mindray, China). The method is based on assaying the residual Fe(II) concentration after adding ferrozine as a chromogenic substrate and incubating the $\mathrm{Fe}(\mathrm{II})$-containing reagent with a serum sample [18]. One unit corresponds to the amount of the enzyme (Cp) in serum that provides oxidation of $1 \mu \mathrm{M} \mathrm{Fe}(\mathrm{II})$ per $1 \mathrm{~min}$ in the medium containing $367 \mu \mathrm{M}$ Mohr's salt (Fe(II) source) in $450 \mathrm{mM}$ sodium acetate buffer ( $\mathrm{pH} 5.8)$. 
To determine serum copper concentration, 4-(3,5-dibromo-2-pyridylazo)- $N$-ethyl- $N$-sulfopropylaniline and trichloroacetic acid as chromogenic and deproteinization agents were used [19]. The ratio between copper and $\mathrm{Cp}$ concentrations was used to characterize copper saturation of $\mathrm{Cp}$.

To determine serum iron concentration, 2-(5-nitro-2-pyridylazo)-5-( $N$-propyl- $N$-sulfopropylamino)phenol and thioglycolic acid as chromogenic and copper-, zinc-masking agents were used [20]. Total iron-binding capacity of serum (TIBC) was determined by adding $10 \mu \mathrm{L}$ of $4.5 \mathrm{mM} \mathrm{FeCl}_{3}$ to $0.25 \mathrm{~mL}$ of serum; iron excess was removed in $10 \mathrm{~min}$ with $20 \mathrm{mg} \mathrm{MgCO}_{3}$. To measure concentration of iron [20] $\mathrm{MgCO}_{3}$ was removed by centrifugation for $15 \mathrm{~min}$ at $3000 \mathrm{~g}$ and the supernatant was used.

Concentration of LDL and high-density lipoproteins (HDL) cholesterol was measured using the kits LDL-CHOLESTEROL-VITAL and HDL-CHOLESTEROL-VITAL (Vital Development Corporation, Russia). The methods are based on selective precipitation of LDL and chromogenic reaction of 4-aminoantipyrine with hydrogen peroxide produced in reaction of cholesterol with the mixture of cholesterol oxidase and cholesterol esterase.

To characterize the specific activity of $\mathrm{Cp}$ and $\mathrm{Tf}$ the ratios of ferroxidase activity to $\mathrm{Cp}$ concentration and TIBC to Tf concentration were used, correspondingly.

The results are represented as a mean \pm standard error of the mean $(M \pm S E M)$, the hypothesis about law of distribution was analyzed by Kolmogorov's test, the equality of variabilities was analyzed as a result of Fisher's test. The equality of expectations was analyzed by one-way ANOVA and post hoc Fisher's LSD test. $P$-values $<0.05$ were considered statistically significant.

\section{Results and discussion}

The table summarizes biochemical variable differences obtained in this study for healthy donors (group 1), for patients with compensated T2D (group 2), and for patients with uncompensated T2D (group 3). The percentage of HbAlc used as a criterion for dividing the individuals into three groups is significantly different in all compared groups. Cp concentration measured using antibody is slightly higher in the $3^{\text {rd }}$ group as compared with the first and the the second groups. On the contrary, the ferroxidase activity of $\mathrm{Cp}$, as well as of serum copper, is decreased in the groups of patients with compensated and uncompensated T2D in comparison with healthy donors. As a result of these changes, a significant decrease of specific ferroxidase activity $(\mathrm{FerOx} / \mathrm{Cp})$ and saturation of $\mathrm{Cp}$ with copper were registered concomitantly with the increase of HbAlc percentage. In case of healthy donors the molar $\mathrm{Cu} / \mathrm{CP}$ ratio very close to 6 was found, which practically corresponds to an expected ratio usually detected in highly purified preparations of $\mathrm{Cp}$ [16]. The data obtained demonstrate that with an increase of hyperglycemia the number of copper ions per one molecule of Cp significantly

Table

Biochemical variable differences in healthy donors (group 1), in patients with compensated T2D (group 2), and in patients with uncompensated T2D (group 3)

\begin{tabular}{|l|c|c|c|c|c|c|}
\hline \multicolumn{2}{|c|}{ Biochemical variable } & \multicolumn{2}{c|}{ M \pm SEM } & \multicolumn{3}{c|}{$p$-values } \\
\cline { 2 - 7 } & $\begin{array}{c}\text { group 1 } \\
(n=110)\end{array}$ & $\begin{array}{c}\text { group 2 } \\
(n=195)\end{array}$ & $\begin{array}{c}\text { group 3 } \\
(n=59)\end{array}$ & $p_{1-2}$ & $p_{1-3}$ & $p_{2-3}$ \\
\hline Glycated hemoglobin (HbA1c), $\%$ & $4.57 \pm 0.08$ & $6.29 \pm 0.02$ & $8.33 \pm 0.20$ & 0.000 & 0.000 & 0.000 \\
\hline Ceruloplasmin $(\mathrm{Cp}), \mathrm{mg} / \mathrm{L}$ & $459 \pm 14$ & $457 \pm 9$ & $518 \pm 10$ & NS & 0.003 & 0.001 \\
\hline Ferroxidase activity of Cp (FerOx), U/L & $817 \pm 23$ & $712 \pm 13$ & $697 \pm 14$ & 0.000 & 0.001 & NS \\
\hline FerOx/Cp, U/mg & $1.78 \pm 0.04$ & $1.56 \pm 0.02$ & $1.35 \pm 0.02$ & 0.000 & 0.000 & 0.000 \\
\hline Serum copper $(\mathrm{Cu}), \mu \mathrm{M}$ & $20.6 \pm 0.7$ & $17.8 \pm 0.4$ & $17.5 \pm 0.4$ & 0.000 & 0.003 & NS \\
\hline Cu/Cp, mole/mole & $5.99 \pm 0.01$ & $5.15 \pm 0.01$ & $4.49 \pm 0.02$ & 0.000 & 0.000 & 0.000 \\
\hline Serum iron (Fe), $\mu \mathrm{M}$ & $18.2 \pm 0.6$ & $18.9 \pm 0.3$ & $18.62 \pm 0.8$ & NS & NS & NS \\
\hline Total iron-binding capacity (TIBC), $\mu \mathrm{M}$ & $49.0 \pm 0.6$ & $47.3 \pm 0.5$ & $47.0 \pm 0.7$ & NS & NS & NS \\
\hline Transferrin $(\mathrm{Tf}), \mathrm{mg} / \mathrm{mL}$ & $2.51 \pm 0.05$ & $3.07 \pm 0.04$ & $3.86 \pm 0.08$ & 0.000 & 0.000 & 0.000 \\
\hline TIBC/Tf, mole/mole & $1.62 \pm 0.02$ & $1.29 \pm 0.01$ & $1.02 \pm 0.01$ & 0.000 & 0.000 & 0.000 \\
\hline LDL cholesterol, mM & $3.26 \pm 0.12$ & $3.38 \pm 0.09$ & $3.43 \pm 0.17$ & NS & NS & NS \\
\hline HDL cholesterol, mM & $1.48 \pm 0.04$ & $1.39 \pm 0.03$ & $1.28 \pm 0.05$ & NS & 0.008 & NS \\
\hline
\end{tabular}

$\mathrm{N}$ o t e. NS $-p$-value is higher than critical value $(p>0.05), 0.000-$ non-zero digit is beyond $3^{\text {th }}$ position after point. 
decreases. In general, these changes correspond to the results of in vitro modification of $\mathrm{Cp}$ by metabolites typical of T2D. Indeed, incubation of Cp with methylglyoxal and aminoacetone is followed by the loss of its copper ions and a decrease of its ferroxidase activity $[5,6]$. We hypothesized that changes in $\mathrm{Cp}$ ferroxidase activity might be compensated by increasing the LDL content. The latter also function as ferroxidase in association with copper ions [13]. However, no significant differences in LDL cholesterol were found among the results of the three groups. Only a slight decrease of HDL cholesterol in the group with uncompensated T2D was found in comparison with healthy donors and patients with compensated T2D.

No significant differences were found in serum iron and total iron-binding capacity of serum (TIBC) among all groups. However, concentration of serum $\mathrm{Tf}$ was higher in patients with compensated T2D as compared with healthy donors, and in patients with uncompensated T2D compared both with patients who had compensated T2D and healthy donors. In contrast, the ratio between TIBC and Tf, which characterizes the specific capacity of $\mathrm{Tf}$ to bind $\mathrm{Fe}(\mathrm{III})$, decreased in patients with compensated T2D in comparison with healthy donors. The same ratio was observed in patients with uncompensated T2D compared either with patients who had compensated T2D or with healthy donors. Indeed, one molecule of Tf can bind two ferric ions. In case of healthy donors, this ratio was 1.6 mole of iron per 1 mole of Tf, but in case of patients with compensated and uncompensated T2D this value was reduced to 1.26 and 1 mole of iron per 1 mole of $\mathrm{Tf}$, respectively. It should be noticed, that such complications of T2D as trophic ulcers are connected with alterations of iron efflux from tissues and the failure of tissues' adaptation to hypoxic stress. Usin natural and non-natural iron chelators, e.g. lactoferrin, which is a homo$\log$ of $\mathrm{Tf}$, can mitigate the severity of T2D and of metabolic syndrome [21].

\section{Conclusion}

In general, activity and concentrations of ironmetabolism proteins, involving in normal transport of iron in blood plasma, were in coincidence: during development of pathological features of hyperglycemia the concentrations of $\mathrm{Cp}$ and of $\mathrm{Tf}$ are rising, but specific activity of these proteins is suppressed. Under normal conditions the activity of proteins participating in iron metabolism, particularly in the transport of that element in plasma, is in conformity with their concentrations. However, the onset of hyperglycemia is followed by an increase of concentrations of both $\mathrm{Cp}$ and $\mathrm{Tf}$ and a concomitant drop of their specific acti- vity. A careful suggestion can be made that elevated concentrations occur in response to the decreasing activity of $\mathrm{Cp}$ and $\mathrm{Tf}$ due to their modification by glucose and its metabolites. The changes observed can explain the efficiency of iron chelators in therapy of such complications of T2D as trophic ulcers that are connected with alterations of iron efflux from tissues.

Funding. This research was supported by grant MK-5874.2018.4.

Ethical approval. This study was approved by The Local ethics committee of the Institute of Experimental Medicine (No. 2/19, 25.03.2019).

Conflict of interest. The authors declare no conflict of interest in financial or any other sphere.

\section{References}

1. Alfadhel M, Babiker A. Inborn errors of metabolism associated with hyperglycaemic ketoacidosis and diabetes mellitus: narrative review. Sudan J Paediatr. 2018;18(1):10-23. https://doi.org/10.24911/SJP.2018.1.3.

2. Yoshida K, Furihata K, Takeda S, et al. A mutation in the ceruloplasmin gene is associated with systemic hemosiderosis in humans. Nat Genet. 1995;9(3):267-272. https://doi. org/10.1038/ng0395-267.

3. Zheng J, Chen M, Liu G, et al. Ablation of hephaestin and ceruloplasmin results in iron accumulation in adipocytes and type 2 diabetes. FEBS Lett. 2018;592(3):394-401. https:// doi.org/10.1002/1873-3468.12978.

4. Pandey R, Dingari NC, Spegazzini N, et al. Emerging trends in optical sensing of glycemic markers for diabetes monitoring. Trends Analyt Chem. 2015;64:100-108. https://doi. org/10.1016/j.trac.2014.09.005.

5. Kang JH. Oxidative modification of human ceruloplasmin by methylglyoxal: an in vitro study. J Biochem $\mathrm{Mol}$ Biol. 2006;39(3):335-338. https://doi.org/10.5483/BMBRep.2006.39.3.335

6. Dutra F, Ciriolo MR, Calabrese L, Bechara EJ. Aminoacetone induces oxidative modification to human plasma ceruloplasmin. Chem Res Toxicol. 2005;18(4):755-760. https://doi. org/10.1021/tx049655u.

7. Squitti R, Mendez AJ, Simonelli I, Ricordi C. Diabetes and Alzheimer's disease: can elevated free copper predict the risk of the disease? J Alzheimers Dis. 2017;56(3):1055-1064. https://doi.org/10.3233/JAD-161033.

8. Sokolov AV, Voynova IV, Kostevich VA, et al. Comparison of interaction between ceruloplasmin and lactoferrin/transferrin: to bind or not to bind. Biochemistry (Mosc). 2017;82(9):1073-1078. https://doi.org/10.1134/ S0006297917090115.

9. Osaki S. Kinetic studies of ferrous ion oxidation with crystalline human ferroxidase (ceruloplasmin). J Biol Chem. 1966;241(21):5053-5059.

10. Golizeh M, Lee K, Ilchenko S, et al. Increased serotransferrin and ceruloplasmin turnover in diet-controlled patients with 
type 2 diabetes. Free Radic Biol Med. 2017;113:461-469. https://doi.org/10.1016/j.freeradbiomed.2017.10.373.

11. Silva AM, Coimbra JT, Castro MM, et al. Determining the glycation site specificity of human holo-transferrin. J Inorg Biochem. 2018;186:95-102. https://doi.org/10.1016/j. jinorgbio.2018.05.016.

12. Misra G, Bhatter SK, Kumar A, et al. Iron profile and glycaemic control in patients with type 2 diabetes mellitus. Med Sci (Basel). 2016;4(4):E22. https://doi.org/10.3390/ medsci4040022.

13. Topham RW, Frieden E. Identification and purification of a non-ceruloplasmin ferroxidase of human serum. J Biol Chem. 1970;245(24):6698-6705.

14. Klenk DC, Hermanson GT, Krohn RI, et al. Determination of glycosylated hemoglobin by affinity chromatography: comparison with colorimetric and ion-exchange methods, and effects of common interferences. Clin Chem. 1982;28(10):2088-2094.

15. Cegla UH. [Serum levels of alpha-2-macroglobulin, ceruIoplasmin, transferrin, alpha-1-antitrypsin and complement (beta-1-C) before and following 3- and 6-day injections of D-penicillamine in man. (In German)]. Z Rheumatol. 1975;34(9-10):301-308.
16. Sokolov AV, Kostevich VA, Romanico DN, et al. Two-stage method for purification of ceruloplasmin based on its interaction with neomycin. Biochemistry (Mosc). 2012;77(6):631838. https://doi.org/10.1134/S0006297912060107.

17. Sokolov AV, Pulina MO, Zakharova ET, et al. Effect of lactoferrin on the ferroxidase activity of ceruloplasmin. Biochemistry (Mosc). 2005;70(9):1015-1019. https://doi. org/10.1007/s10541-005-0218-9.

18. Erel 0 . Automated measurement of serum ferroxidase activity. Clin Chem. 1998;44(11):2313-2319.

19. Abe A, Yamashita S, Noma A. Sensitive, direct colorimetric assay of copper in serum. Clin Chem. 1989;35(4):552-554.

20. Yamashita $S$, Abe A, Noma A. Sensitive, direct procedures for simultaneous determinations of iron and copper in serum, with use of 2-(5-Nitro-2-pyridylazo)-5-(N-propyl$\mathrm{N}$-sulfopropylamino)phenol (Nitro-PAPS) as ligand. Clin Chem. 1992;38(7):1373-1375.

21. Elizarova AYu, Kostevich VA, Voynova IV, Sokolov AV. Lactoferrin as a promising remedy for metabolic syndrome therapy: from molecular mechanisms to clinical trials. Med Acad J. 2019;19(1):45-64. https://doi.org/10.17816/ MAJ19145-64.

\section{Information about the authors / СвеАения об авторах}

Irina $V$. Voynova - PhD student, Research fellow of the Department of Molecular Genetics, Institute of Experimental Medicine, Saint Petersburg, Russia. E-mail: iravoynova@mail.ru.

Valeria A. Kostevich - PhD (Biology), Senior Researcher of the Department of Molecular Genetics, Institute of Experimental Medicine, Saint Petersburg, Russia. https:// orcid.org/0000-0002-1405-1322: SPIN-code: 2726-2921. E-mail: hfa-2005@yandex.ru.

Anna Yu. Elizarova - PhD student, Research fellow of the Department of Molecular Genetics, Institute of Experimental Medicine, Saint Petersburg, Russia. SPIN-code: 3059-4381. E-mail: anechka_v@list.ru.

Marina N. Karpenko - PhD (Biology), Senior Researcher of The Pavlov Department of Physiology, Institute of Experimental Medicine, Saint Petersburg, Russia. https:// orcid.org/0000-0002-1082-0059; SPIN-code: 6098-2715. E-mail: mnkarpenko@mail.ru.
Ирина Витальевна Войнова - аспирант, научный сотрудник отдела молекулярной генетики, ФГБНУ «Институт экспериментальной медицины», СанктПетербург. E-mail: iravoynova@mail.ru.

Валерия Александровна Костевич - канд. биол. наук, старший научный сотрудник отдела молекулярной генетики, ФГБНУ «Институт экспериментальной медицины», Санкт-Петербург. https://orcid.org/00000002-1405-1322: SPIN-код: 2726-2921. E-mail: hfa-2005@ yandex.ru.

Анна Юрьевна Елизарова - аспирант, научный сотрудник отдела молекулярной генетики, ФГБНУ «Институт экспериментальной медицины», Санкт-Петербург. SPIN-код: 3059-4381. E-mail: anechka_v@list.ru.

Марина Николаевна Карпенко - канд. биол. наук, старший научный сотрудник физиологического отдела им. И.П. Павлова, ФГБНУ «Институт экспериментальной медицины», Санкт-Петербург. https:/orcid. org/0000-0002-1082-0059; SPIN-код: 6098-2715. E-mail: mnkarpenko@mail.ru. 
Alexey V. Sokolov - Doctor of Biological Sciences, Head of the Laboratory of Biochemical Genetics of the Department of Molecular Genetics, Institute of Experimental Medicine; Saint Petersburg; Professor of Chair of Fundamental Problems of Medicine and Medical Technology at Saint Petersburg State University, Saint Petersburg, Russia. https://orcid.org/0000-0001-9033-0537; SPIN-code: 74277395. E-mail: biochemsokolov@gmail.com.

\section{Corresponding author / Контактное ^ицо}

Alexey V. Sokolov / Алексей Викторович Соколов

E-mail: biochemsokolov@gmail.com
Алексей Викторович Соколов - д-р биол. наук, заведующий лабораторией биохимической генетики отдела молекулярной генетики, ФГБНУ «Институт экспериментальной медицины», Санкт-Петербург; профессор кафедры фундаментальных проблем медицины и медицинских технологий ФГБОУ ВПО «Санкт-Петербургский государственный университет», СанктПетербург. https://orcid.org/0000-0001-9033-0537; SPINкод: 7427-7395. E-mail: biochemsokolov@gmail.com. 